at length, and rightly so, on the highly developed national consciousness of the Czech peasantry during 1848 , as compared with that of other Slavic peasants, and sees it as a function of class struggle: Czech peasants versus German landlords. An unexceptionable observation no doubt, but having made it, he considers the problem solved. Other explanations, notably the question of literacy, are not explored: because literacy among the Czechs exceeded that of other Slavic nationalities by a considerable margin, Czech leaders had an advantage in disseminating nationalist ideas amid their constituency.

It may be asking too much that such points should have been considered. These are relatively recent approaches, and the present work was completed ten years ago. Rosdolsky has not been vouchsafed the opportunity of seeing his work through to publication; he died in 1967 in the United States, a country which he adopted as an immigrant after World War II and where he pursued the life of a private scholar.

Stanley Z. Pech

University of British Columbia

\title{
POLITIKAI ANTISZEMITIZMUS MAGYARORSZÁGON, 1875-1890. By Judit Kubinszky. Budapest: Kossuth Könyvkiadó, 1976. 275 pp. $25 \mathrm{Ft}$.
}

Little scholarly work has been done on the origins and manifestations of modern antiSemitism in Hungary. There are, of course, general histories of the Jews in Hungary and a number of articles, mainly by Western scholars, which deal with the problem. The work under review; however, is the first monographic study of anti-Semitism as a political movement.

Judit Kubinszky describes in detail many aspects of the first great wave of antiSemitism to occur in Hungary in the late 1870 s and early 1880 s during the long tenure of Liberal Prime Minister Kálmán Tisza. She places her study in a European context by sketching the development of political anti-Semitism after 1848 in Germany, Russia, Rumania, Italy, and France. She links the rise of anti-Semitism in Hungary to the civil emancipation of the Jews between 1848 and 1867 and to the rapid development of capitalism, both of which facilitated the rise of Jews to prominence in economic and social life. It is not surprising, therefore, that anti-Jewish sentiments were strongest among those groups that felt Jewish competition most keenly. Kubinszky dates the beginning of an organized anti-Semitic movement from the speeches of Gyözö Istóczy in the Hungarian parliament in 1875. A hitherto undistinguished deputy of the Liberal Party, Istóczy attained quick notoriety by playing upon widely held suspicions that the Jews were secretly pursuing the subjugation of Christians through economic monopoly, and by demanding that the government thwart such designs by returning to preemancipation policies.

In her analysis of anti-Semitic ideology, based upon the extensive propaganda literature of the period, including Istóczy's own newspapers, Jövönk (Our Future) and 12 Röpirat (Twelve Pamphlets), Kubinszky reveals the great variety of motives behind Hungarian anti-Semitism. The notorious Tiszaeszlár trial of 1883, in which fifteen Jews stood accused of the "ritual murder" of a Christian girl, and the countrywide disturbances which followed their acquittal are treated at length and enable the author to demonstrate once again how pervasive anti-Jewish feeling had become. The trial resembles the later Dreyfus case, because the issues it raised transcended questions of individual guilt or innocence and became a general contest between liberal and conservative forces. Riding the crest of popular feeling, Istóczy founded the Anti-Semitic Party in 1884, but, as Kubinszky shows in a detailed examination of the electoral 
campaign of that year, the new party had very little in the way of a coherent program, few candidates of any stature, and almost no local organization. Ineptness also characterized the few deputies who won seats in parliament-seventeen instead of the seventy predicted by Istóczy-and by the end of the decade, the party had disintegrated and anti-Semitism had receded into the political background.

This book is certainly a useful introduction to an important problem, but much remains to be done. For example, we need to know more about the anti-Jewish sentiments of the various social classes, particularly the urban workers and the peasantry, the connection between anti-Semitism and nationalism, and the extent of anti-Semitism among the non-Magyar population of Hungary. The author's succinct account of the Tisza government's opposition to anti-Semitism is of particular interest; she emphasizes the fact that anti-Semitism did not become a decisive factor in Hungarian political life as it did in neighboring countries, precisely because it lacked official support. Yet, her explanation is limited to political tactics of the moment. A more thorough investigation of the nature of Hungarian liberalism would suggest more profound reasons for the course anti-Semitism took in Hungary.

\section{KeIth Hitchins University of Illinois at Urbana-Champaign}

COMPARATIVE PATTERNS OF FOREIGN POLICY AND TRADE: THE COMMUNIST BALKANS IN INTERNATIONAL POLITICS. By Cal Clark and Robert L. Farlow. Studies in East European Planning, Development, and Trade, no. 23 (July 1976). Bloomington: International Development Research Center, Indiana University, 1976. xii, 152 pp. $\$ 6.00$, paper.

Foreign trade may be conducted to obtain goods from abroad which are unavailable in the domestic market, to benefit from comparative exchange advantage, or to promote political objectives. The interrelatedness of these goals often makes it difficult to sort out the structure of cause and effect, especially when a large variety of goods are traded and political motives are complex. Cal Clark and Robert Farlow, though aware of these complicating factors, nonetheless try to show that the foreign trade pattern of the Communist Balkans can be understood in terms of shifting political policies and fluctuations in the relative priority accorded to political and economic objectives.

The first chapter provides an overview of postwar developments in the foreign policies of Yugoslavia, Rumania, Albania, and Bulgaria; and the second outlines how foreign trade is institutionally determined. The narrative is documentary in style and makes no attempt to discriminate interpretation from fact. The rest of the book is articulated in the same way. Changing patterns of interbloc and intrabloc foreign-trade volumes and structures are described and imputed to diverse causes-sometimes political, sometimes economic, sometimes both.

Because the basis for the authors' causal attributions are never rigorously elaborated, it is difficult to appraise their inferences. They "eyeball" the time trend of various trade flows, and from an infinity of possible causal explanations, manage to find political and/or economic reasons for every squiggle in the trend line. Although the reasons they provide are often "reasonable," the real burden of analysis falls upon the reader, who must continually try to imagine alternative interpretations of the squiggles, fill in the logical substructure of Clark and Farlow's assertions, and then evaluate their comparative merit. Burdening the reader in this manner, of course, is unworkable, and in the end one is faced with the choice of trusting the authors' subconscious judgmental faculties or discarding their analysis entirely. 